\section{PSIHOANALITIČKA \\ STUDIJA O IZVORIMA \\ KREATIVNOSTI \\ PETRA LUBARDE}

\section{Srđa Zlopaša}

UDK: 614.253:616.89-008.44

Klinika za psihijatriju, Klinički centar Srbije, Srbija

\section{Kratak sadržaj}

Petar Lubarda spada u red najvećih jugoslovenskih i evropskih slikara XX veka. Jedini je jugoslovenski umetnik čiji je rad reprodukovan $\mathrm{u}$ "Istoriji modernog slikarstva“ Herberta Rida. Petar Lubarda je jedan od primera kako rana obilježenost može biti plodan izvor stvaralaštva. Lubardina tematska preokupiranost krševitim predelima svog rodnog kraja Ljubotinja i stare Crne Gore je nešto po čemu je Lubarda bio i ostao prepoznatljiv. Rodni kraj nije puki geografski lokalitet već je to složen amalgam potisnutih sećanja, likova, emocija, slika, kolorita, scena, zvukova i glasova, fragmenata predstava i još mnogo čega. Ljudi se razlikuju i prema tome kakav odnos gaje prema rodnom kraju. Jedni negiraju tu vezanost, drugi ostaju zarobljeni u okvirima lokalnog a retki uspevaju da kreativno prorađuju rane i temeljne utiske potekle iz najranijeg perioda života , Lubarda nesumnjivo spadau ove poslednje te kako sam kaže- "To viđenje djetinstva zauvijek ostaje, taj pečat..I umjetnik se sam uvijek vraća tim svojim korijenima. Dolazi u zavičaj jer ga to vuče. Taj svijet djetinjstva, ta etika, čine mu suštinu stvari. Frojd se u svom najranijem i najinspirativnijem delu "Pesnik i fantaziranje" iz 1908. bavi poreklom umetničke kreativnosti. Na samom početku Frojd se pita- "Odakle ta čudnovata ličnost, pesnik, uzima svoju građu..? " i traži odgovore u dečijoj igri, dnevnim snovima, fantaziji. Tako u umetničkom delu Frojd prepoznaje "...elemente nedavnog povoda, kao $i$ stare uspomene." Analiza dela Petra Lubarde uporedo sa značajnim biografskim podacima otvara inspirativno interpretativno polje. Cilj ovog rada je da baci svetlo na određene aspekte Lubardine kreativnosti, premda bi detaljna studija analize ovog područja zahtevala mnogo više vremena i prostora.

Ključne reči: psihoanaliza, kreativnost, Petar Lubarda, psihobiografija 


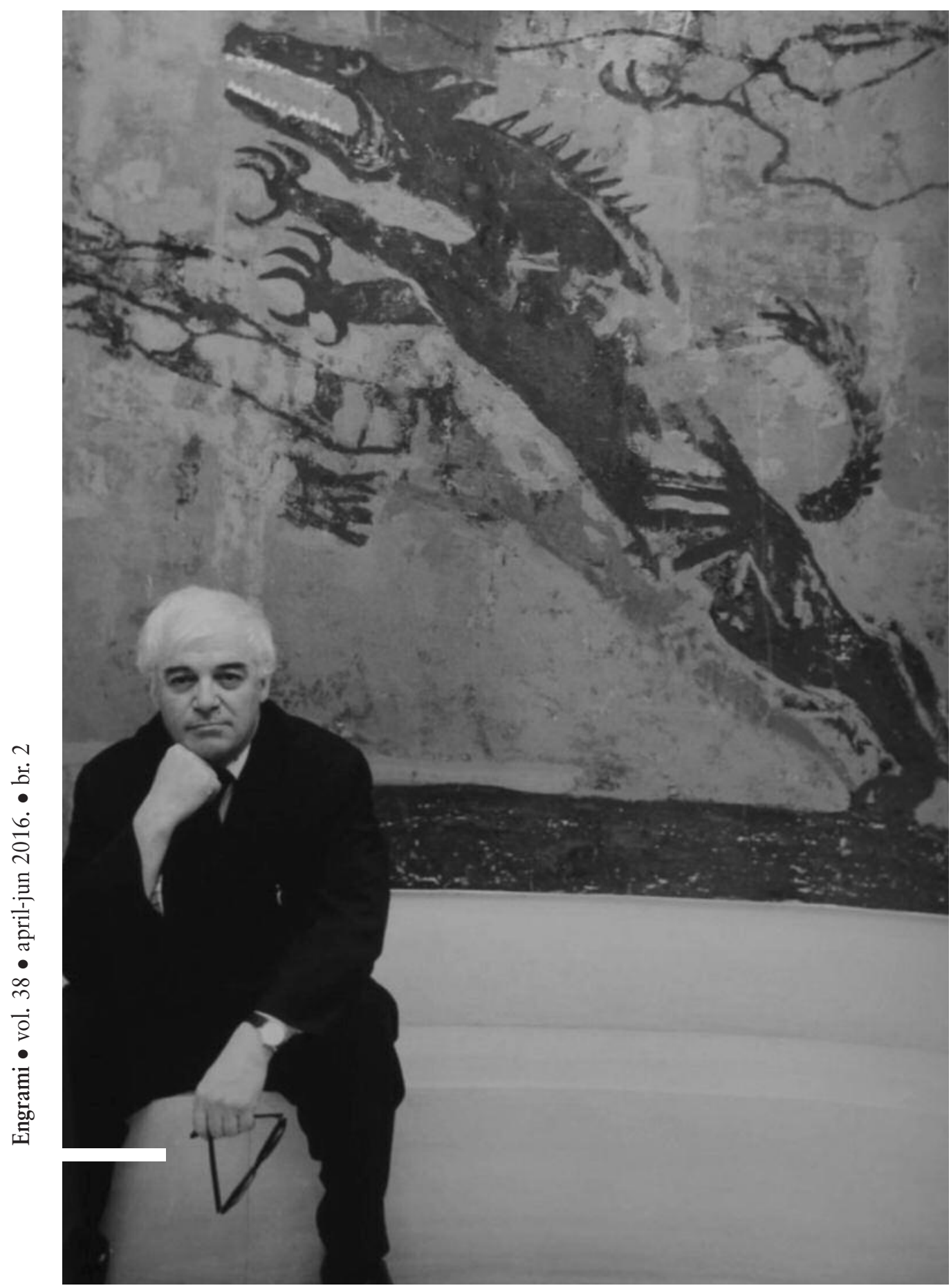

Petar Lubarda (1907-1974) 


\section{IZ BIOGRAFIJE}

Petar Lubarda spada u red najvećih jugoslovenskih i evropskih slikara XX veka. Po narodnosti se izjašnjavao kao Srbin što je imao potrebu da naglasi u više pismenih dokumenata kao u pismu koje se danas čuva u arhivu SANU čiji je član bio. Rođen je 27.7.1907 u Ljubotinju na prostoru Riječke nahije na teritoriji Stare Crne Gore. Rođen je kao prvo od šestoro dece Đura, oficira crnogorske vojske i Marije Lubarde, domaćice [1]. Školovao se u rodnom Ljubotinju, Cetinju, Splitu, Sinju, Nikšiću, Herceg Novom. Prvu samostalnu izložbu ima kao đak gimazije u Nikšiću 1925 [1). Pohađa Umetničku školu u Beogradu ali ubrzo odlazi u Pariz gde isto tako kraće pohađa Akademiju lepih umetnosti. Nikada nije kompletirao formalno slikarsk obrazovanje što dosta govori o njegovoj prirodi. Prvi put samostalno izlaže u Rimu 1929. Godine. 1932 vraća se $\mathrm{u}$ Jugoslaviju, ženi se Jelenom Jovanović studentkinjom istorije umetnosti. Izlaže u paviljonu „Cvijeta Zuzoric“". Na Svetskoj izložbi u Parizu 1937. dobija nagradu Grand Prix. U Hagu na internacionalnoj izložbi 1939. Dobija prvu nagradu. Po izbijanju Drugog svetskog rata biva mobiliziran u Jugoslovensku Kraljevsku Vojsku kada je zarobljen. Ratne godine provodi $\mathrm{u}$ logorima $\mathrm{u} \mathrm{Au}-$ striji i Italiji. Kraj rata označava povratak u domovinu i niz tragičnih gubitaka. 1945. od tuberkuloze mu umire brat Veljko. Iste noći po rođenju umire mu i muško dete rođeno $u$ vanbračnoj zajednici. Komunističke vlasti ubijaju Petrova oca Đura Lubardu oficira Kraljevske vojske. Razvodi se od Jelene Jo- vanović Lubarda. Posle rata radi kao profesor na Akademiji likovnih umetnosti do 1946. Ženi se mladom Verom Protić tada studentkinjom slikarstva. Vraća se kratko na Cetinje gde je prvi direktor Umjetničke škole. Od 1950. Živi u Beogradu. Te godine izlaže na XXV Bijenalu u Veneciji. Priređuje samostalnu izložbu u Parizu 1952. Završava veliku zidnu kompoziciju Boj na Kosovu za svečanu dvoranu NR Srbije. Za sliku Borba konja dobija nagradu 1953. u Sao Paolu, 1953. Gdje je proglašen za glavno otkriće bijenala. Dobija nagradu u Tokiju za sliku Noć u Crnoj Gori i veliki broj internacionalnih i domaćih priznanja. Postaje najistaknutiji moderni slikar tog vremena. Jedini je jugoslovenski umetnik čiji je rad reprodukovan u "Istoriji modernog slikarstva“ Herberta Rida. Umro je 13. februara 1974. godine u Beogradu [1].

\section{UVOD}

Uporedna analiza uticaja psiholoških faktora i biografskih podataka na kreativni proces i stvaranje umetničkog dela zahtevan je i izazovan posao iz više razloga, zbog obilja asocijacija koje te iz neminovnosti redukcije složenih psiholoških procesa, neizbežnih zamki, identifikacije idealizacije, preterane kritičnostinaspram osobina autora čije se delo proučava. Kao peteča svih savremenih psihobiografskih studija uzima se "Jedna uspomena iz detinjstva Leonarda Da Vinčija" Sigmunda Frojda iz 1910 [2]. Od tada se psihobiografske tendencije razvijaju u više pravaca kao psihoanalitičke studije umetnikovog nesvesnog i analize reprezenata psihoseksualnih 
stadijuma razvoja ličnosti u umetničkom delu, zatim, psihobiografske studije o uticaju duševnih bolesti na stvaralaštvo, te razmatranje večne dileme odnosa "genija i ludila". Frojd je hrabro iskoračio u tumačenju odnosa biografija umetnika i njihovih dela. Prvenstveno je odabrao stvaraoce za koje je smatrao da predstavljaju vrhunac svetske misli i estetike-Dostojevski, Gete, Mikelanđelo [3]. Taj hrabar iskorak nije prošao bez rizika i neminovnih grešaka. Premda Frojd nije pisao celovite psihobiografije, več je uzimao markantne segmente koje je smatrao za bremenite nesvesnim psihološkim značenjem. Najveća zamerka Frojdovoj analizi života dela velikih umjetnika je redukcionistički pristup koji je proistekao iz njegove fascinacije tada sveže formulisanim psihoseksalnim stadijima razvoja ličnosti. Redukcionizam, u ovom slučaju predstavlja svođenje i objašnjenje složenih psihičkih fenomena oralnim, analnim, uretralnim, falusnim i edipalnim karakteristikama. Međutim, savremena psihoanaliza ne negirajući validnost osnovnih gradivnih blokova psihoseksualnog razvoja ističe važnost nadgradnje i multifaktorijalnost u oblikovanju psihičkog života i stvaralaštva. Premda obilježena neizbežnim redukcionizmom Frojdova psihoanalitička tumačenja biografskih podataka velikih umetnika su kamen temeljac i nepresušni

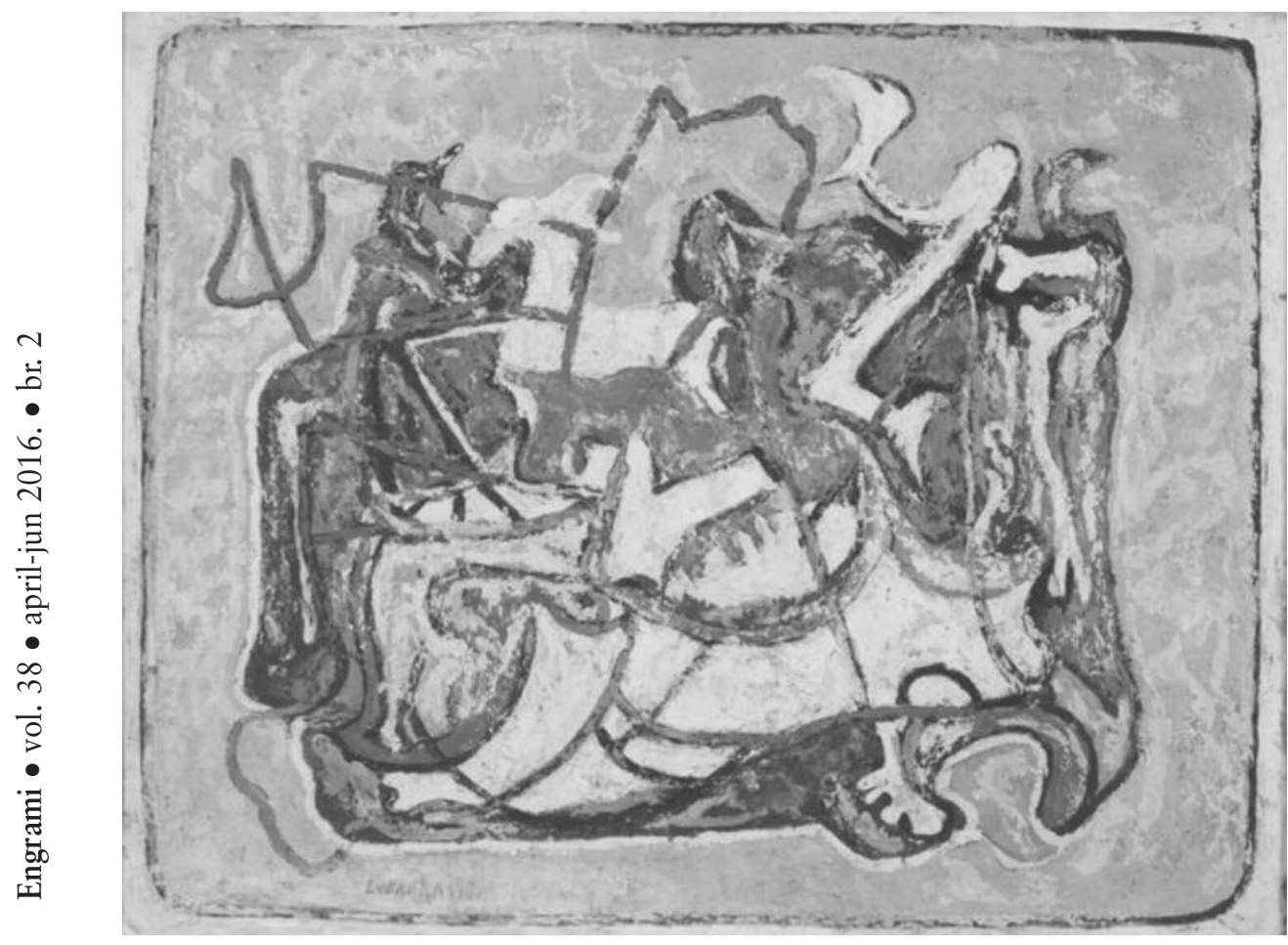

Kompozicija/ 1952. / ulje na platnu / $98 \times 79 \mathrm{~cm}$ /

Composition 1952. / oil on canvas / $98 \times 79 \mathrm{~cm} /$ 
izvor psihobiografskih studija. Frojd se u svom najranijem i najinspirativnijem delu "Pesnik i fantaziranje" iz 1908. bavi poreklom umetničke kreativnosti. Na samom početku Frojd se pita- “Odakle ta čudnovata ličnost, pesnik, uzima svoju građu..? " i traži odgovore u dečijoj igri, dnevnim snovima, fantaziji [4]. Tako u umetničkom delu Frojd prepoznaje “... elemente nedavnog povoda, kao i stare uspomene." Analiza dela Petra Lubarde uporedo sa značajnim biografskim podacima otvara inspirativno interpretativno polje.

Prateći Frojdovo traganje za izvorištima kreativnosti u detinjstvu postavljamo pitanje- kada se umjetnik rađa i kada se javlja ta prva "iskra koja pronalazi svoj udar u kamenu?" [4]. Njegoševa misao kaže da nije udarca o kamen, iskre koja iz kamena zaiskri ne bi ni bilo, jer bi "u kam očajala" iskra bi bez udarca ostala potencijal zarobljen u kamenu. Prirodnjačkim rečnikom izraženo Njegoševa misao se može transponovati u odnosu urođenog i sredinskog (nature vs. nurture) u čijem susretu se odvija život i kreativnost. Ne slučajno, kreativnost Petra Lubarde se prvo izrazila u kamenu da bi kroz kasniji opus kamen ostao njegova primarna fascinacija. Lubardin svet kao da počinje $\mathrm{u}$ kamenu. "Petar je proo crtao po kamenu" [5]. Premda je sam Frojd bio skeptičan po pitanju mogućnosti potpunog psihološkog razumevanja fenomena umetničke kreativnosti nije odoleo da kroz optiku psihoanalize-discipline koju je stvorio baci pogled na tu neosvojenu teritoriju ljudske duše. Tako je i ova kratka studija o izvorima kreativnosti Petra Lubarde, pokušaj čitanja kroz Frojdovu optiku u kombinaciji sa savremenim psihoanali- tičkim stremljenjima uz priznavanje neizbežne interpretativne subjektivnosti.

\section{RODNI KRAJ}

Petar Lubarda je jedan od primera kako rana obilježenost može biti plodan izvor stvaralaštva. I laiku je poznata tematska preokupiranost krševitim predelima svog rodnog kraja Ljubotinja i stare Crne Gore. Rodni kraj nije puki geografski lokalitet većje to složen amalgam potisnutih sećanja, likova, emocija, slika, kolorita, scena, zvukova i glasova, fragmenata predstava i još mnogo čega. Ljudi se razlikuju i prema tome kakav odnos gaje prema rodnom kraju. Jedni negiraju tu vezanost, drugi ostaju zarobljeni u okvirima lokalnog a retki uspevaju da kreativno prorađuju rane i temeljne utiske potekle iz najranijeg perioda života [6], Lubarda nesumnjivo spadau ove poslednje. "To viđenje djetinstva zauvijek ostaje, taj pečat..I umjetnik se sam uvijek vraća tim svojim korijenima. Dolazi u zavičaj jer ga to vuče. Taj svijet djetinjstva, ta etika, čine mu suštinu stvari." [7]. Lubardino vraćanje u rodni kraj je ponajmanje fizičko, ono je duhovno, pogotovo u svojoj kasnijoj najmarkantijoj fazi stvaralaštva koja je prezasićena "kamenim morem" njegovog rodnog kraja. Psihološko vraćanjena prošle stadijume koji pripadaju prošlosti otvara i pitanje složenog fenomena regresije. Lubarda ima potrebu za intenzivnom vizuelnom, likovnom i emotivnom komunikacijom sa osnovnim vizurama krajolika u kojima je proteklo njegovo rano formiranje. Komunikacija sa prošlim je jedna vrsta vraćanja ili regresije. Stvaralački proces podrazumeva dinamičnu fluktuaciju, 
alternaciju između svesnih i nesvesnih procesa. Regresija koja je kanalisana i koja ima (pa makar i nejasnu ciljnu predstavu) dozvoljava proboj nesvesnih sadržaja [8]. U čemu bi bila važnost, specifičnost i uloga regresivnih elemenata u Lubardinom stvaralaštvu? Pre svega potreba zavraćanjem ali u cilju prorade i restrukturiracije prošlog a ne u cilju pukog reprodukovanja zapamćenog. Poznato je da je veliki broj slika u njegovoj najpoznatijoj fazi prikazivao krš crnogorskih planina. Pre svega ovde primećujemo repetitivnost određene teme što ukazuje ukazuje na subjektivnu važnost iste za autora. Repetitivnost, dalje, upućuje na vezanost i kompulziju ka vraćanju, a sve u cilju prorađivanja primarnih ličnih datosti. Zamislimo samo koliko vremena je Lubarda morao provoditi slikajući krš, biti suočen sa tom svojom temom koja se ponavlja. Ovdje se naravno objektivno hronološko vrijeme ne podudara sa subjektivnim psihološkim vremenom. U procesu kreativnog stvaranja subjektivno vrijeme zauzima primat, tako da trajanje suočenosti sa temom koja se obrađuje poprima aspekte nesvjesnog koje ne poznaje protok vremena.Kako sam Lubarda kaže-“" U jezgru života vreme je nemerljivo. "Sadržaji nesvesnog žive onoliko koliko i njihov vlasnik. "Znate, ako se zagledate ko šta radi,još je to uvijek jedan zid, jedan kamen. Uvijek kao jedan zapis." [8].

Lubardini povratci su kreativni, oni kao koriste osnovnu građu ranih impresija da bi je dekonstruisali, preoblikovali i dozvolili jači proboj unutrašnjeg doživljaja od onog vizuelnog." Umjetnik možda ne mora biti fizički u sredini gdje je roden ali crpe snagu iz te sredine. To umjet- nika manje više prati $i$, zapravo to mu je neki praizvor." Praćenjem životnog puta Petra Lubarde kao da osjećamo neku vrstu unutrašnje predodređenosti za nezaustavljivo napredovanje a pri tom ne poštivanje formalnih obrazovnih zahtijeva. Ta unutrašnja opredeljnost za samoostvarivanje morala je biti usađena jako rano, a to znači u odnosu sa primarnim objektom. Potraga i nepormirljivost za individualnim izrazom obilježila je èitav Lubardin životni put, zapažamo je još na samom poèetku životnog puta koji je neodvojiv od umetnièkog traganja.

Dete se pre biološkog rođenja stvara u fantaziji roditelja, a te fantazije podrazumijevaju i očekivanja vezana za izbor i nasleđivanje profesije. Petar Lubarda je rođen kao najstarije muško dete u oficirskoj porodici, otac je očekivao da Petar krene njegovim stopama. Petar nije postao vojnik ali su teme njegovih najpoznatijih ostvarenja prikazivala velike nacionalne historijske bitke. Lubarda je bio fasciniran sukobom kao opštom ljudskim konstantnom. Druga tema koja ima svojstva repetitivnosti u njegovoj najprepoznatljivijoj fazi od kraja četredetih su prikazi velikih bitaka i bojeva. Jedno od očiglednih objašnjenja jeste odrastanje na naraciji narodne epike ali pored toga tema sukoba mora imati važno unutrašnje individualno značenje. Slikar je prolazio kroz mnoge spoljne i unutrašnje bitke od kojih su neke završavale gubicima, ali nisu označavale predaju, Lubardina borba bila je večna. Lubardin likovni kosovski ciklus proističe iz fascinacije simbolikom ove istorijske bitke. 


\section{PRVA SEĆANJA}

Dečije uspomene pokrivalice služe i kao paravan koji skriva moćna osećanja vezana za bolne i konfliktne teme koje osetljiva dečija duša ne može lako da podnese. "Majka mu je govorila da je bio najosetliiviji od sve njene dece na udare groma i blesak munje, što ga je noću držalo budnim" [8]. Lubarda je èesto usporeðivao boje i zvukove, nije iskljuèeno da je posedovao osobine iz spektra sinestezija. "Često, idući kroz pejzaž Crne Gore, koji ja rado slikam, vidim razne događaje. Ponekad mi se čini da se vrhovi brda i škarpe pretvaraju u zouk «(P.Lubarda) [7]. Bazična osetljivost i plašljivost na spoljne podražaje upućuje na kasniju umetničku senzibilnost sa kojom se preovladavaju ti strahovi. Ovladanjem svetlom i zvukom kreativnim preoblikovanjem suruvog sveta dete $\mathrm{u}$ umetniku izlazi na kraj sa onim što je strašno i preteće. Lubardina svedočenja puna su slikovitih i intenzivnih sećanja iz ranog detinjstva. Tako upečatljivo sećanje o orlu koji nosi u kljunu zmiju, podseća na mitologijske scene, borbe dobra i zla, gde dečak doživljava fascinaciju snagom koja trijumfuje nad zlom zmijom, ali i po klasičnom frojdijanskom tumačenju ukazuje na kastrativne strahove. Apstrahujući konkretne detalje, sećanje dakle počinje borbom-konfliktom što je jedan od centralnih motiva Lubardinog slikarstva. Drugo sjećanje je kada mali Petar pita rođaka sa kojim putuje od Cetinja ka rodnom Ljubotinju kako to da je Lovćen drugačiji, kako se oni pomeraju? Rođak pokušava da se našali odgovorom da ga Bog pomera i zaustavlja kada se oni osvrnu, na šta dobija neočekivano ljutit odgovor:" $\mathrm{E}$, ti si budala." Ovde vidimo pre svega rane naznake vizuelne psihološke orijentacije, osjetljivost i zapitanost nad fenomenima prostornosti, daljine i perspektive. Dalje, neočekivano nepristajanje dječaka na obmanu, laž i podčinjavanje autoritetu što se kasnije sreće u različitim kontekstima u daljem umjetnikovom životu. Postoji još jedna interpretativni kanal, naime, mali Petar podizan na usmenoj narodnoj tradiciji osjeća veličinu i simboliku Lovćena i kao da se pita dalje kakvo je njegovo mjesto u svijetu i kosmosu i u kakvom je on odnosu sa njim. Nepristajenje na „pomjeranje Lovćena“ on mnogo godina kasnije izražava i svojim angažovanjem $u$ peticiji protiv rušenja Njegoševe grobne kapele premda pokazuje poštovanje prema Meštrovićevoj umetnosti. Dakle ovde uviđamo izraženu ambivalenciju prema autoritetu. Ambivalencija može poticati i od dva lica oca koja je doživljavo, strogog čoveka, koji ga kori da se bavi nečim ozbiljnijim u životu od crtanja, ali isto tako onog koji mu poklanja bojice " $d a$ bi se zadovoljio" kako otac govori. U ovoj dvosmislenoj poruci otac kao da stimuliše $u$ sinu onaj dio koji kod sebe nije razvijao zbog vojne karijere (voleo je rezbarenje). Iza sećanja i portreta starog crnogorskog kapetana , a inače je nerado crtao portrete kao da se krije potraga za dobroćudnim autoritetom. Naime, stari penzionisani kapetan je primjetio dečakov dar u crtanju te mu je kupovao bojice koje su se teško u to vreme nalazile, iz zahvalnosti je nastao navedeni portret starog kapetana u crnogorskoj nošnji naslonjene glave ne koščatu desnicu, a što je sve Lubarda ispričao kasnije svom 
starijem kolegi slikaru Milu Milunoviću [10].

Naslućujemo da su pitanja vezana za vizuelno i estetsko od egzistencijalnog značaja za budućeg umjetnika i da će tim putevima izražavati svoje najdublja osećanja, sukobe i doživljaj svijeta. Na ranim fragmentima Lubardinih sećanja uočavamo izraženu dječiju znatiželju i tragove jakog skopofilnog istraživačkog nagona koji predstavlja preduslov za bilo koji oblik kreativnosti. Na mestima koja su data ,zdravo za gotovo “budući umetnik, istraživač, prvo postavlja pitanje u fazi inkubacije koje dekonstruiše dato stanje i iz gradivnih blokova razgrađenih pojmova, ideja, utisaka gradi novu celinu [1].

\section{STILSKI OBRT}

Lubarda je u svom opusu prošao kroz više razvojnih faza a najznačajniji je stilski obrt $u$ ranom posleratnom period gde se sve više udaljava od klasičnog ka ekspresivnom, modernom izrazuLubardina dekonstrukcija postaje osnova kasnijeg čuvenog obrta (1946-7) u stilu, koji teži da iz očigledne, zadate forme kreira individualno viđenje prebojeno dominantnim koloritom unutrašnjeg sveta, kako sam Lubarda kaže- "....da stvaram umjetnost,pravu umjetnost, a da govori kroz nju što mi iznutra misao diriguje." [7]. Tako npr. klasične teme iz nacionalne istorije, pejzaže rodnog kraja Lubarda vidi na svoj osoben način te čini da i gledalac dela doživi na novi, drugačiji način, a što sve počiva na osobini da se usudi da razgradi očigledno i na razvalinama stvori svoju, novu monumentalnost. Iz ove anegdote koja se urezala u sjećanje moglo bi seizvesti još predznaka kasnijih duševnih odlika, spomenuli smo odnos prema autoritetu, mali dječak se drčno suprostavlja starijem rođaku, a mnogo godina kasnije se čudi kako i batine nije dobio. Dete se prije biološkog rođenja stvara $u$ fantaziji roditelja, ate fantazije podrazumevaju i očekivanja vezana za izbor i nasleđivanje profesije. Petar Lubarda je rođen kao najstarije muško dijete $\mathrm{u}$ oficirskoj porodici, otac je očekivao da Petar krene njegovim stopama. Petar nije postao vojnik ali su teme njegovih najpoznatijih ostvarenja prikazivala velike nacionalne bitke. Lubarda je bio fasciniran sukobom kao opštom ljudskim konstantnom.Ta tema koja ima svojstva repetitivnosti u njegovoj najprepoznatljivijoj fazi od kraja četredetih jesu prikazi velikih bitaka i bojeva. Jedno od očiglednih objašnjenja jeste odrastanje na naraciji narodne epike ali pored toga tema sukoba mora imati važno unutrašnje individualno značenje. Slikar je prolazio kroz mnoge spoljne i unutrašnje bitke od kojih su neke završavale gubicima, ali nisu označavale predaju, Lubardina borba bila je večna.

Prikazujući monumentalnost bitaka on platno koristi kao ekran za projekciju ličnih konfliktnih sadržaja u sukob koji se odigrava $\mathrm{u}$ istorijskom kontekstu. Lični i opšti fatum ljudskog društva se kondenzuju u tematici večnih sukoba. "Lubarda otkriva na svojim platnima ovu veliku istinu, i ovaj dramatični sukob."(P.Milosavljević,1951). Dve prekretnice, lična i umetnička koincidiraju u nekoliko godina 1945 sa kulminacijom izložbom 1951. 1945. godina je obilježena sa više tragičnih gubitaka, a dolazi posle dugog 
i iscrpljujućeg zarobljeništva obilježenog sa brutalnim suočenjem sa ljudskom bestijalnošću i smrću.

\section{GUBICI}

Streljanje nevinog oca, smrt brata, smrt muškog deteta na rođenju, zvanični razvod od dotadašnje supruge. Ovi gubici se dešavaju paradoksalno na završetku Drugog Svetskog rata, posle kulminacije destrukcije i smrti, u osjetlivom trenutku kada je iscrpljen i obilježen logorskim iskustvom mogao pomisliti da je najgore prošlo. Ovakava tragična koncidencija i broj gubitaka bitnih osoba kod prosečne osobe bi mogao izazvati depresivnu dekompenzaciju i stanje prolongiranog tugovanjasa inhibicijom produktivnosti. Ovo nije bio slučaj sa Lubardom, on kao da svoju unutrašnju tragediju rešava sublimacijom i bezpoštednim radom. Od tog perioda se postepeno smanjuje broj ljudskih figura i likova na Lubardinim slikama (sem kao učesnicima velikih bitaka). Lubarda $u$ tom periodu gotovo da prestaje da se zanima ljudsku individu i telo, upadljivo je i odsustvo ženskog akta. Lubarda se strasno posvećuje krajolicima koji su pusti, psihoanalitičkim rečnikom bezobjektni ili bi mogli reći kao da su arhaični unutrašnji objekti lišeni svesne nadgradnje. Nestajanje ljudskih bića sa platana odvija seantropomorfizacija krajolika, stene, planine, useci kao da preuzimaju ulogu ljudskih objekata. Strasan kolorit i zahvat četkicom nadomješćuju afektivnu izražajnost ljudske telesne i facijalne ekspresije. Da li je Lubarda ispraznio svoja platna od ljudi usled unutrašnje povređenosti i opustošenosti, ostaje otvoreno pitanje? Kada prikazuje sela svog rodnog kraja ne naziremo tra- gove ljudskog prisustva, kuće postaju subjekti koji preuzimaju ulogu ljudi.Puste okućnice nastavljaju da pričaju price isčezlih stanara.Tako na primer "Kamena pučina" iz 1951. kao da prikazuje projekciju unutrašnje okamenjenosti i opustošenosti, ali tu na scenu opet stupa borba, jer Lubarda se ne predaje, svojim čuvenim koloritom vraća intenzivne emocije, njegova pobuna je pobuna bojom. Lubardin zaokret u stilu može se analizirati sa aspekta dešavanja $u$ kontekstu ondašnjih svetskih likovnih trendova ali ta radikalna promena mora biti povezana i sa ličnim tokovima. Kakvu sudbinu su u unutrašnjem slikarevom životu imala osećanja besa i krivice zbog nepravednog ubistva oca, tuga zbog gubitka brata, muškog potomka i supruge? Takva osoba morala je upotrebiti jake psihološke odbrambene mehanizme. U osnovi svakog stvaralaštva nalazi se kapacitet za sublimacijom što predstavlja svojstvo da se sirova, intenzivna i preteća osećanja preoblikuju u umetničko delo. Lubarda posle ovih traumatičnih gubitaka ne prestaje da stvara, ova osećanja kao reka ponornica svom silinom izbijaju na površinu na njegovim platnima $u$ vidu prepoznatliive oštre forme i snažnog kolorita. Gubitak bazičnih životnih struktura koincidira sa restrukturacijom slikarskog izraza koji traži novu komunikativnu dimenziju.

\section{TAJNA SNAGE LUBARDINOG IZRAZA}

To možda daje odgovor na pitanje u čemu je tajna komunikativnosti i intenzivnosti Lubardinih dela. Prigušena osećanja posle dubokog potiskivanja i unu- 
trašnje elaboracije iskazuju se u svoj silini. Kada Predrag Milosavljević piše o Lubardinom drveću koje simbolizuje život koji crpi svoju snagu iz dubina, mraka, nepoznatog tj.nesvesnog kaže “...raste neko čuno drveće, mrkozeleno, skoro crno, i bujno i sočno kao da ga je napajala neka neizmerna podzemna voda." Ospoljavanje unutrašnjeg sukoba kod gledaoca i kritičara uspevaju da pobude čitav spektar kontrasnih osećanja. Tako opet Milosavljević piše: "Podjednako dramatično, elementarno, ozbiljno i strogo..." a Isidora Sekulić: "Njegov predeo zato stoji pred nama izazvan, razdražen i agresivan, ali osvojen i savladan...", dok Protić B. Miodrag nalazi: "U akordima plavog, belog i zlatnožutog, crvenog i zelenog ima toliko zdravlja mladosti i optimizma...". Zbog te svoje fascinacije kršem i epskim temama kritike pisane na račun Lubardinih dela često su znale da zapadnu u melodramatski ton u cilju glorifikacije nacionalne epopeje, međutim dubina, značenje sukoba imaju opšteljudski i kosmološki karakter. "Meni nije bio niuzeo kao jedno od osnovnih odlika umetnika. Jaka sklonost ka dnevnom sanjarenju inzenzivira u trenutcima kada je stvarnost posebno okrutna. To dnevno fantaziranje uvek ima jaku vizuelnu komponentu i predstavlja fazu pripreme i inkubacije za nastanak određenog dela. $\mathrm{U}$ isto vreme to sanjarenje vrsta bega od realnosti, umetnost je slikarev odbrambeni mehanizam i sredstvo da se sa surovom realnošću izađe na kraj. To nije neka potreba za spoljnim estetizovanjem već dramatičan čin unutrašnje borbe koja biva ospoljena na platnu. "Umjetnost, ako želi da izrazi jednu stranu života, doživljaj, ne samo onaj optički nego $i$ onaj psihički..."(P.Lubarda). Za vreme ograničene šetnje u logoru, zaboravio je kada se treba vratiti, zagledao se preko žica " ...u neko crijeće, i neku šumicu I tako nešto razmišljao, ili bolje reći gledao $i$ ne razmišljao ništa..." kada ga je spazio logorski čuvar obratio mu se na njemačkom na šta je Petar odmahnuo rukom te se razbjesnio. Za takav incident se $\mathrm{u}$ logoru lako mogla izgubiti glava. Analizom drugih Lubardinih dnevnih sanjarenja uviđamo motive koji u kasnijoj fazi zauzimaju dominantno mesto, fantazije prirode te unutrašnja borba i etičke dileme. Sekundarnom revizijom primarnih emocionalnih konflikata isti se pomeraju i rešavaju u arabesknim fantazijama prirode.

Pitamo se kojim psihološkim putevima pored slikarskih umeća Lubarda ostvaruje afektivnu komunikativnost iintenzitet doživljaja kod posmatrača? U specifičnoj moći neverbalne komunikacije narelaciji nesvijesno umetnika i nesvijesno pomatrača leži trajnost, bezvremenosti snaga poruke. U tom leži večna svežina i intenzitet Lubardibih dela. Traženjem svog specifičnog izraza koje je kulminiralo čuvenim zaokretom 
ka slobodnijem asocijativnom slikarstvu Lubarda pronalazi način da eksternalizuje snagu svog unutrašnjeg konflikta, neprestane borbe i da energija unutrašnjeg doživljaja bude vernije prenešena. Tu se traganje i razvoj sopstvenog ličnog i profesionalnog identiteta odvijaju ka slobodnijoj formi koja se postupno udaljava realističnog izraza. „Za mene je bilo glavno odstraniti sve elemente koji tematski koèe, da bi forma $i$ boja bile u proom planu."Lubarda traži naèin da ispolji svoje unutrašnje afektivne i idejne vulkane, u èemu nesumljivo uspeva. Obrt iz pedesetih godina predstavlja sraz unutrašnje borbe i težnje da se oslobodi stega i izrazi snaga i težina unutrašnjeg sveta slikara koji je opet poprište sukoba slika i emocija iz prošlosti koje traže svoj izraz i razrešenje." To je rvanje sa nevidljivim koje mora postati vidljivo."Tu kreativni proces ima svoje komunikativno ali katarktièko terapijsko dejstvo. Gledalac biva uvuèen u konflikt intenzivnije nego li da je prikaz realistièan. Snaga sukoba kome se prepuštamo omoguæujue prenošenje na unutrašnji svijet posmatraèa dela i otvara moguænost katarze. Lubarda pobuðuje temeljnu zapitanost; šta je to unutrašnji svet i u kakvom je odnosu sa spoljašnjom realnošæu? Nagomilano iskustvo kao odraz kontakta i konflikata sa spoljnim svetom, složeni talozi odraza spoljašnjeg. Lubardine slike mogu da posluže kao dobra ilustracija I odgovor, kako izgleda taj unutrašnji svet? Slike deponovane $u$ sjeæanju podležu složenim procesima obrade i transformacije, kao i u svetu snova. Dolazi do pomeranja, kondenzacije, sinteze predstava, misli ioseæanja koja se fuzionišu u potpuno novi konstrukt. Uzmimo na primjer poznatu sliku guslara. Lubarde se seæa kako je ova predstava iz ranog djetinjstva koja je bila realan doživljaj koji je kasnije transponovana u delo kakodanas vidimo. Oko jedne slike kao grozd se kupi mnoštvo drugih ideja koje su praæene razlièitim emotivnim nabojem, kasnija intelektualna elaboracija daje formu i objašnjenje jednom takvom utisku. Lubarda otvara moguænost da mimo optièke realne slike na platno izaðe ovaj nesvesni kontekst koji zapravo prenosi emotivnu poruku snage, krika, tragedije, patosa, dileme, smrtnosti...Tako je Lubarda svojim stilom uspeo da pronaðe izraz koji pomiruje zakone primarnog nesvesnog procesa i vidljivog, svesnog, vizuelnog, a taj njegov hod po granici je njegova specièna snaga izraza po kojoj je prepoznatljiv. 


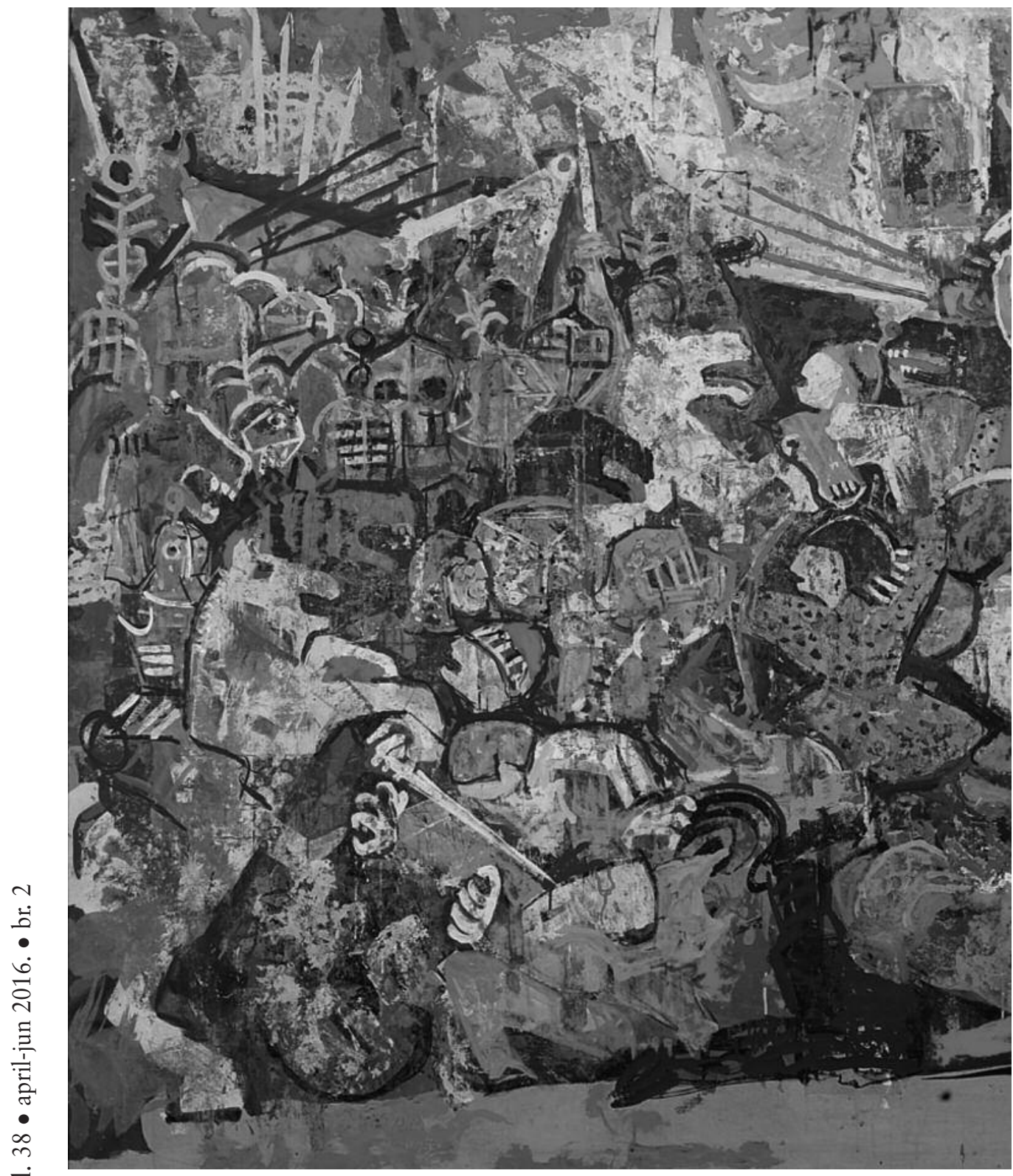

Kosovska bitka / 1953. / kombinovana tehnika/platno / 172,5×190,5 cm / Battle of Kosovo / 1953. /combined technique /canvas / 172,5×190,5 cm / 


\title{
A PSYCHOANALYTIC STUDY OF PETAR LAUBARDA'S GENESIS OF CREATIVITY
}

\author{
Srdja Zlopasa
}

Clinic for Psychiatry, Clinical Center of Serbia, Belgrade, Serbia

\begin{abstract}
Summary
Analysing how psychological factors and biographical data make an impact on the creative process and the creation of a work of art is a demanding and challenging task for many reasons: an abundance of associations emerging from an analysis of biographical data; the necessity to reduce complex psychological processes; an inevitable pitfall of idealisation or excessive criticism of an author and an work of art. The questions are: When is an artist born? When does that fi rst "spark which fi nds in contact with a stone its way out" appear? Peter Lubarda is an example of how being predestined in early years of life can be a fruitful source of creativity. Our place of origin is not just a geographical point. It is a complex amalgam of repressed memories, personalities, emotions, images, colours, scenes, sounds and voices, fragments of conceptions and a lot more. People differ from one another also according to what kind of a stand they take on their place of origin. Some deny their attachment, whereas others remain trapped within the local. However, there are a few of those who manage to process their initial and crucial impressions from the earliest period of their lives creatively. Lubarda undoubtedly belongs to the last group. "That vision of childhood always remains, that mark ... An artist alwaysreturns to his roots. He goes back to his place of origin because he is drawn by it. That world of childhood, those ethics, colour the essence of things." Lubarda keept going back to his homeland in a least physical way; it was spiritual, especially in the latter most signifi cant phase of his creative work. Psychological regression to those previous life stages which belong to the past brings up the issue of the aforementioned complex psychological phenomenon. Lubarda had the need for an intensive visual, artistic and emotional communication with his intial visions of the landscape in which he had sent his early years growing up. Communication with the past is a kind of going back or regression. The process of creating involves a dynamic fluctuation of conscious and unconscious processes. When it is channelled and has even a vague target conception, regression allows those unconscious contents to come out to the
\end{abstract}


surface. What would be the relevance, distinctiveness and role of those regressive elements in Lubarda's creative work? First of all, his need to go back is for the purpose of processing and restructuring the past, and not for the purpose of reproducing simply what he had harboured as a memory. It is a well-known fact that a great number of his paintings from the most famous artistic period represent the Karst in Montenegro. To start with, here we notice repetitiveness of a subject. And this fact reveals subjective importance of that subject for the author. Furthermore, repetitiveness indicates his attachment and compulsion to go back, with the aim of processing his principal personal givens.Imagine how much time Lubarda had to spend painting the Krast and to face this repetitive subject of his. Here, of

course, the objective chronological timeline does not coincide with his subjective psychological time. During the process of creating, the subjective time takes primacy. Therefore, the length of facing the subject one isworking on takes on aspects of the unconscious which is unfamiliar with the passage of time. "At the core of life, time is immeasurable." Contents of the unconscious live as long as their "owner" is alive. "You know, if you observecarefully who is doing what, it is still a wall, a stone. Always in form of a record entry." (P. Lubarda, 1968).

Key words: psychobiography, Petar Lubarda, psychoanalysis, creativity

\section{Literatura}

1. Kuća Legata. Legat Petra Lubarde. Beograd.2014.

2. Frojd S. Antropološki ogledi.Str 419. Prosveta, Beograd. 2005.

3. Frojd S. Antropološki ogledi. Str 353. Prosveta, Beograd. 2005.

4. Njegoš P.P Gorski vijenac. Čigoja, Beograd. 2001.

5. Doner Vera rođ.Lubarda. Video snimak za potrebe Legata Petra Lubarde, 2014.

6. Zlopaša S. Snovi, sjećanja i fantazije u filmovima Federika Felinija. Engrami 2010; 32 (1-2): 51-58.

7. Perović O. "Petar Lubarda 1907-1974" Galerija Tiodorović 2004

8. Zlopaša S.. On regression-many faces of one phenomenon. Engrami 2011: 33 (2): 7384.

9. Živković S. "Lubarda Petar" Radionica duše, Beograd 2004.

10. Brajović A. "Slika i misao Petra Lubarde" Zvonik, Beograd, 2001 